\title{
MODEL PENGENDALIAN SOSIAL PREVENTIF DALAM MENANGANI PENYIMPANGAN PERILAKU WISATAWAN MANCANEGARA DI KABUPATEN BADUNG
}

\author{
Fitri Amalia Rhamadani ${ }^{1}$, I Ketut Suwena ${ }^{2}$, L.G.L.K. Dewi ${ }^{3}$ \\ Email: amaliarhamadani@student.unud.ac.id ${ }^{1}$, suwenaketut31@gmail.com², \\ leli_ipw@unud.ac.id ${ }^{3}$ \\ ${ }^{1,2,3}$ Program Studi Industri Perjalanan Wisata, Fakultas Pariwisata, Universitas Udayana
}

\begin{abstract}
Deviations in the behavior of foreign tourists often occur in Badung Regency. Forms of deviant behavior include aggressive behavior, behavior against authority, disrespectful behavior and stupid behavior. The need for a preventive social control effort in anticipating the occurrence of deviations in the behavior of foreign tourists in the future. Determination of informants using purposive sampling and snowball sampling. Data collection is done by observation, interviews, literature study, and documentation. Data analysis techniques using qualitative analysis with the creditability test and the dependability test. The discussion resulted in a model of the construction display framework of preventive social control in Badung Regency, which was formed based on facts or the phenomenon of behavior deviations that often occur. In the introduction of the forms of deviant behavior of foreign tourists there are 4 forms and have a total of 17 behaviors and the total forms of such deviations require social control with a preventive approach. In the preventive approach there are 10 ways that can control foreign tourists to deviate. The role of tourism stakeholders (local communities, government and tourism entrepreneurs) is needed to distribute Do's and Don't's in Bali brochures. The brochure will later contain supporting pictures or illustrations to attract the reader's interest, understand the meaning in each sentence. Preventive social control material by dividing 3 material is presented, namely: Do's in Bali, Do's in Bali, and Why in Bali. After the mechanism for distributing brochures is carried out by stakeholders and there is still a deviation of tourist behavior, the next stage of violators will be subject to sanctions.
\end{abstract}

\begin{abstract}
Abstrak: Penyimpangan perilaku wisatawan mancanegara kerap terjadi di Kabupaten Badung, bentuk penyimpangan perilaku tersebut meliputi perilaku agresif, perilaku menentang otoritas, perilaku tidak sopan dan perilaku bodoh. Diperlukannya suatu upaya pengendalian sosial preventif dalam mengantisipasi terjadinya penyimpangan perilaku wisatawan mancanegara di masa mendatang. Penentuan informan menggunakan purposive sampling dan snowball sampling. Pengumpulan data dilakukan dengan observasi, wawancara, studi kepustakaan, dan dokumentasi. Teknik analisis data menggunakan analisis kualitatif dengan uji kreditabilitas dan uji depentabilitas. Pembahasan menghasilkan satu model kerangka display konstruksi dari pengendalian sosial preventif di Kabupaten Badung dibentuk berdasarkan fakta ataupun fenomena penyimpangan perilaku yang kerap terjadi. Dalam pengenalan bentuk-bentuk penyimpangan perilaku wisatawan mancanegara terdapat 4 bentuk dan memiliki total 17 perilaku dan total bentuk penyimpangan tersebut memerlukan pengendalian sosial dengan pendekatan preventif. Dalam pendekatan preventif terdapat 10 cara yang bisa mengendalikan wisatawan mancanegara melakukan penyimpangan. Untuk dibutuhkan peran stakeholder pariwisata (masyarakat lokal, pemerintah dan pengusaha pariwisata) menyebarkan brosur Do's and Dont's in Bali. Brosur nantinya akan berisi gambar atau ilustrasi pendukung untuk menarik minat pembaca, memahami maksud dalam setiap kalimat. Materi pengendalian sosial preventif dengan membagi 3 materi disajikan, yaitu: Do 's in Bali, Dont's in Bali, dan Why in Bali. Setelah mekanisme penyebaran brosur dilaksanakan oleh stakeholder dan masih terjadi penyimpangan perilaku wisatawan, tahapan selanjutnya para pelanggar akan dikenakan sanksi.
\end{abstract}

Keywords: model, social control, foreign tourist, badung regency. 


\section{PENDAHULUAN}

Dewasa ini Bali sudah cukup berhasil dalam meningkatkan jumlah kunjungan wisatawan mancanegara ke Kabupaten Badung. beberapa tahun-tahun terakhir timbul fenomena penyimpangan perilaku yang dilakukan wisatawan mancanegara. Menurut Bidell dan Deacon (2010: 10) bahwa perilaku menyimpang disebut sebagai seseorang yang "nakal" dan kategori perilaku mengganggu yang mereka tampakkan bisa digolongkan berat sebagai perilaku misbehavior atau misconduct. Menurut Charles dalam Pia Todras (2007: 4) Misbehavior atau kelakuan buruk atau perbuatan yang tidak baik adalah perilaku yang dianggap tidak pantas untuk situasi tertentu. Missbehavior sendiri memiliki bentuk-bentuk penyimpangan perilaku yaitu aggression / berperilaku agresif atau menyerang, immorality (berperilaku tidak sopan), defiance of authority (menentang otoritas), dan clowning around (berperilaku bodoh).

Di Kabupaten Badung ditemukan bentuk penyimpangan perilaku wisatawan mancanegara meliputi 4 variabel bentuk-bentuk penyimpangan, yaitu perilaku agresif terdiri atas : ODGJ, pengeroyokan, penganiayaan, pengerusakan, pembunuhan, berkelahi dan mengamuk. Perilaku tidak sopan, terdiri atas : tidak menghormati peraturan adat Bali, menaiki pura, menampar petugas imigrasi, tidak berbusana / berbusana minim. Perilaku menentang otoritas terdiri atas : pelanggaran lalu lintas, overstay, begpacker. Perilaku bodoh terdiri atas : merusak motor sewaan, freestyle di jalan raya, meninggalkan motor sewaan tidak membayar.

Hal ini diperlukannya sebuah model untuk menangani penyimpangan perilaku wisatawan. Menurut Murty, et al (1990) Model merupakan suatu representasi yang memadai dari suatu sistem, dan dikatakan memadai jika telah sesuai dengan tujuan dalam pikiran peneliti. Sedangkan menurut Gordon (1978) Suatu kerangka utama informasi sistem yang dikumpulkan untuk mempelajari sistem tersebut. Dalam membentuk suatu model dalam mengangani penyimpangan perilaku wisatawan mancanegara diperlukan penerapan pengendalian sosial secara preventif
Menurut Darmadi (2012: 3) dilihat dari sifat dan tujuannya, terdapat tiga kategori bentuk pengendalian, yaitu : preventif; pengendalian represif; dan pengendalian gabungan antara pengendalian preventif dan represif. Pengendalian preventif merupakan usaha yang dilakukan untuk mencegah terjadinya penyimpangan terhadap norma dan nilai sosial yang berlaku di masyarakat. Alasan yang mendasar dari penulisan artikel ini adalah maraknya penyimpangan perilaku wisatawan mancanegara, dimulai dari melanggar normanorma, seperti: agama; kesusilaan; kesopanan; kebiasaan dan hukum. Sebagai upaya pengendalian preventif dalam menangani penyimpangan perilaku tersebut diperlukan sebuah model pengendalian sosial, sehingga dapat menghasilkan analisis pengendalian sosial yang lebih tepat, untuk menekan atau mengurangi penyimpangan perilaku wisatawan mancanegara di masa mendatang.

\section{METODE}

Survey ini dilakukan di Kabupaten Badung, dengan wisatawan mancanegara yang berlibur di Kabupaten Badung sebagai kawasan favorit saat berlibur. Pesatnya pertumbuhan kunjungan wisatawan mancanegara di Kabupaten Badung menimbulkan beberapa penyimpangan perilaku. Variabel yang digunakan yaitu model pengendalian sosial preventif. Teknik pengumpulan data dilakukan dengan observasi, wawancara, studi kepustakaan, dan dokumentasi. Teknik penentuan informan dilakukan dengan snowball sampling dan purposive sampling, penentuan informan menggunakan purposive sampling untuk menentukan informan pangkal dan informan kunci dan penggunaan snowball sampling untuk menentukan informan komunitas yang terselubung, isu-isu yang sulit diungkapkan dengan jelas atau tidak terlihat nyata, isu-isu komunikasi, dan lain sebagainya. Sedangkan teknik analisis data menggunakan analisis data kualitatif, dengan uji validitas dan uji kreditabilitas.

\section{HASIL DAN PEMBAHASAN}

Kabupaten Badung memang menjadi lokasi favorit wisatawan mancanegara 
melakukan perjalanan ke beberapa destinasi wisata yang terkenal. Alhasil dalam beberapa tahun terakhir terjadinya beberapa fenomena penyimpangan wisatawan mancanegara di Kabupaten tersebut. Sikap wisatawan yang tidak terkontrol dan terkesan semena-mena terhadap masyarakat lokal dan menjadikan korban dalam proses pariwisata. Akibatnya masyarakat lokal yang merasa dirugikan dan mulai risih terhadap tingkah laku wisatawan mancanegara yang menyimpang.

Menurut Doxey (1976) dengan teori irritation index dalam buku Pitana menjelaskan untuk mengetahui sikap masyarakat lokal dalam menanggapi kegiatan pariwisata termasuk wisatawan yang berada di daerah mereka. Terdapat empat fase yaitu euphoria, apathy, annoyance, dan antagonism. Saat ini masyarakat Bali khususnya Kabupaten Badung sudah memasuki fase annoyance, arti masyarakat hampir mencapai titik jenuhnya dalam menerima kehadiran wisatawan bahkan mulai terganggu dengan kegiatan pariwisata yang ada atau karena perilaku wisatawan mancanegara tersebut. Perencanaan yang dilakukan lebih ke arah peningkatan sarana prasana dan bukan menekan pertumbuhan melainkan menimbulkan penyimpangan terhadap norma dan nilai sosial.

Pengendalian sosial preventif merupakan usaha yang dilakukan untuk mencegah terjadinya penyimpangan terhadap norma dan nilai sosial yang berlaku di masyarakat. Pengendalian ini dilakukan sebelum terjadinya penyimpangan dengan maksud untuk pencegahan sedini mungkin, menghindari kemungkinan terjadinya tindakan penyimpangan perilaku wisatawan mancanegara di Kabupaten Badung. Berikut ini merupakan model pengendalian sosial dalam menangani penyimpangan perilaku wisatawan mancanegara di Kabupaten Badung. Display konstruksi konseptual yang dibuat secara abstraksi berbasis data yang ditemukan peneliti diuraikan sebagai berikut:

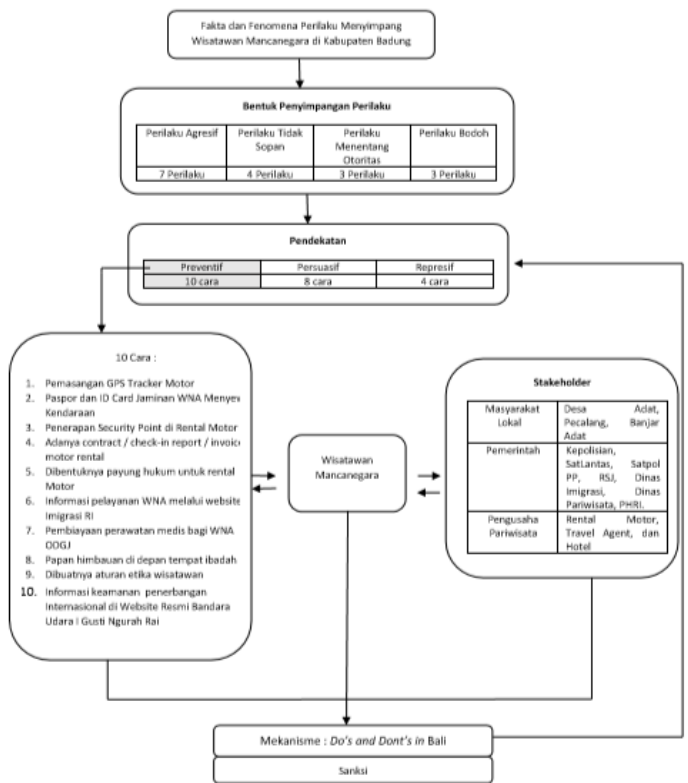

Gambar 1. Model Display Konstruksi

Berdasarkan gambar 1 model merupakan suatu model preventif yang dapat dibentuk berdasarkan fakta ataupun fenomena yang sedang berkembang, dalam pengenalan bentukbentuk penyimpangan perilaku wisatawan mancanegara ditemukan 4 bentuk dan memiliki total 17 perilaku. Dari total bentuk penyimpangan tersebut dibutuhkannya pengendalian sosial dengan 3 pendekatan. Namun dalam artikel ini, berfokus pada pendekatan preventif. Dalam pendekatan preventif terdapat 10 cara yang bisa mengendalikan wisatawan mancanegara melakukan penyimpangan dan dibutuhkannya peran stakeholder pariwisata ikut menjalankan pengendalian sosial secara preventif ini. Stakeholder yang bahwa ini terdapat masyarakat lokal; pemerintah dan pengusaha pariwisata. Pengendalian sosial yang dilakukan oleh masyarakat lokal di Kabupaten Badung, diartikan sebagai salah satu merupakan Desa Adat. Hal ini yang menjadi menarik karena Desa Adat mendapat peran penting dari penanganan penyimpangan perilaku wisatawan.

Menurut PERGUB Bali No 4 Tahun 2019

Desa Adat adalah kesatuan masyarakat hukum adat di Bali yang memiliki wilayah, kedudukan, susunan asli, hak-hak tradisional, harta kekayaan sendiri, tradisi, tata krama pergaulan 
hidup masyarakat secara turun-temurun dalam ikatan tempat suci (kahyangan tiga atau kahyangan desa), tugas dan kewenangan serta hak mengatur dan mengurus rumah tangganya sendiri. Desa Adat yang tumbuh berkembang selama berabad-abad serta memiliki hak asal usul, hak tradisional, dan hak otonomi asli mengatur rumah tangganya sendiri, telah memberikan kontribusi sangat besar terhadap kelangsungan kehidupan masyarakat dalam berbangsa dan bernegara; hukum adat berdasarkan filosofi Tri Hita Karana yang berakar dari kearifan lokal Sad Kerthi, dengan dijiwai ajaran agama Hindu dan nilai-nilai budaya serta kearifan lokal yang hidup di Bali, sangat besar peranannya dalam pembangunan masyarakat, bangsa, dan negara sehingga perlu diayomi, dilindungi, dibina, dikembangkan, dan diberdayakan guna mewujudkan kehidupan Krama Bali yang berdaulat secara politik, berdikari secara ekonomi, dan berkepribadian dalam kebudayaan.

Maka dari itu, setelah peran dari stakeholder dan penerapan pendekatan preventif dengan 10 cara diterapkan kepada wisatawan mancanegara, dibutuhkannya pendekatan preventif lain dengan penerapan mekanisme pembuatan brosur Do's and Dont's in Bali. Menurut Courtland L. Bovee (1995:7) sebagai bentuk penyampaian informasi produk, jasa atau ide-ide melalui komunikasi nonpersonal yang biasanya menggunakan biaya pemasangan, dan biasanya juga disampaikan secara persuasif serta diidentifikasikan sebagai sponsor dalam berbagai macam media. Brosur yang diartikan dalam artikel ini berbentuk selebaran yang terlipat, yakni terdiri atas selembar kertas yang dikemas dengan cara lipat terdapat dua lipatan, dan menghasilkan enam halaman. Bentuk atau cara melipatnya disesuaikan dengan rancangan (desain) yang digunakan mengikuti garis horizontal. Kegiatan penyampaian informasi dalam brosur, pada dasarnya merupakan bentuk komunikasi nonpersonal, karena dilakukan melalui perantara media. Pada pelaksanaanya, penyampaian informasi tak hanya dilakukan dengan komunikasi personal saja, tetapi juga menggunakan komunikasi personal. Artinya dalam brosur tersaji materi penjelasan yang memadukan gambar atau ilustrasi lengkap dengan keterangan pada gambar tersebut. llustrasi dalam sebuah brosur akan menarik minat pembaca untuk menerapkannya dalam kehidupan sehari-hari. Penulis mengkemas materi pengendalian sosial preventif dalam konteks himbauan dan sedikit pemahaman tentang perilaku yang bisa dilakukan dan yang tidak bisa dilakukan di Bali. Diharapkan dengan adanya penyebaran brosur ini nantinya dapat mengedukasi wisatawan mancanegara dalam mengantisipasi ketidak-tahuannya akan normanorma yang berlaku di Bali. Berikut brosur Do's and Dont's in Bali (halaman depan) :

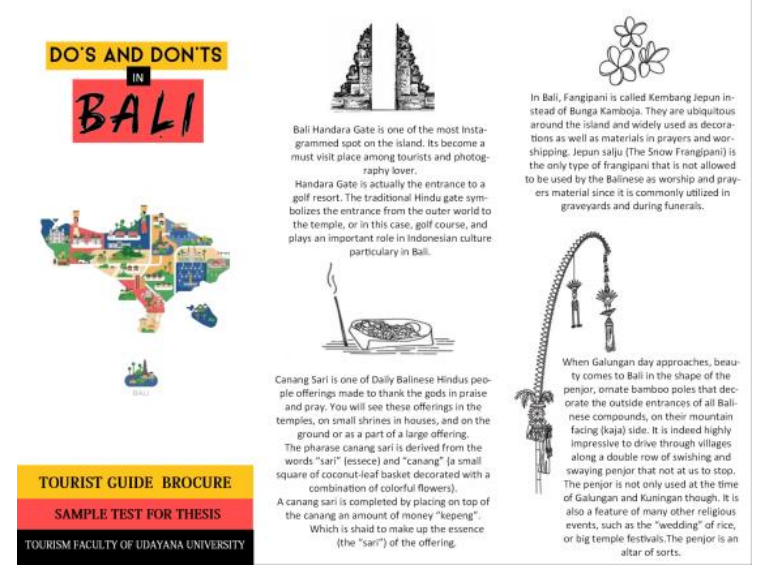

Gambar 2. Halaman depan

Berdasarkan gambar 2 pada halaman depan atau sampul dari brosur terdapat judul brosur yang bertuliskan 'Do's and Dont's in Bali" dengan ikon Pulau Bali untuk mempertegas lokasi yang terkandung dalam brosur ini. Penambahan keterangan pada bawah brosur terdapat kolom yang bertuliskan "Tourist Guide Brocure, Sample Test for Thesis, Tourism Faculty of Udayana University". Halaman selanjutnya, terdapat ilustrasi atau gambar pendukung tentang beberapa penjelasan ikon yang menjadi ciri khas Bali, seperti: pengertian Bali Handara Gate, Canang Sari, Fangipani, dan Penjor. Berikut brosur Do's and Dont's in Bali (halaman belakang) : 

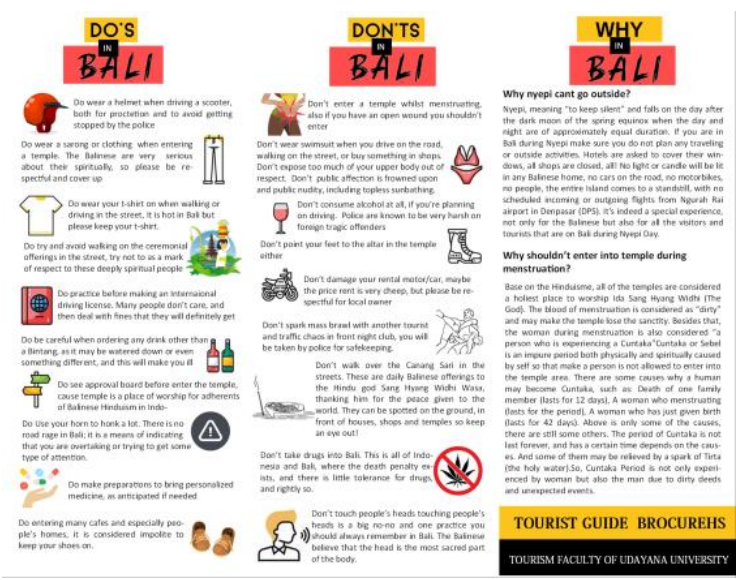

Gambar 3. Halaman belakang

Berdasarkan gambar 3 pada halaman belakang terdapat uraian tiga kategori materi, yaitu: Do's in Bali; Dont's in Bali; dan Why in Bali. Penentuan materi ini berdasarkan hasil survey yang dilakukan oleh penulis, dimana masih banyak penyimpangan yang terjadi, dikarenakan kurangnya pemahaman wisatawan mancanegara saat berlibur di Bali khususnya di Kabupaten Badung. Oleh karena itu penetapan materi ini diharapkannya dapat menjadi acuan wisatawan mancanegara sebelum berlibur. Materi penjelasan pada halaman Do's in Bali merupakan perilaku yang diwajibkan saat berlibur di Kabupaten Badung untuk tetap mengikuti norma yang berlaku di Bali, yaitu: menggunakan helm saat berkendara; mengunakan celana panjang/sarung saat memasuki pura; menggunakan kaos/atasan saat berkendara; tidak mencoba melintas melewati masyarakat lokal yang sedang melakukan upacara; berhati-hati dalam memesan minuman alkohol selain bir Bintang/arak; gunakan bel pada motor saat berkendara; membawa obatobatan pribadi; dan melepas sepatu ketika masuk rumah warga.

Materi penjelasan pada halaman Dont's in Bali merupakan perilaku yang dilarang saat berlibur di Kabupaten Badung serta mengikuti norma yang berlaku di Bali, yaitu: tidak masuk ke dalam pura jika sedang menstruasi; tidak menggunakan bikini jika berjalan-jalan, atau membeli sesuatu; tidak berjemur tanpa menggunakan pakaian sehelai pun; tidak mengkonsumsi alkohol ketika akan berkendara; tidak menggunakan sepatu saat memasuki pura; tidak merusak motor sewaan; tidak menginjak canang sari dijalan; tidak membawa narkoba; tidak menyentuh kepala masyarakat lokal itu tidak sopan.
Materi penjelasan pada halaman Why in Bali merupakan perilaku yang dilarang saat berlibur di Kabupaten Badung serta mengikuti norma yang berlaku di Bali, yaitu: mengapa saat nyepi tidak diperkenankan keluar dan mengapa saat menstruasi tidak diperkenankan masuk ke dalam pura. Penentuan materi "tidak dapat keluar saat nyepi" berdasarkan hasil survey yang dilakukan penulis, telah terjadi fenomena seorang wisatawan mancanegara yang menginap dikawasan Desa Adat Kampial membuat geger disaat Catur Brata Penyepian 25 Maret 2020. Wisatawan asal Amerika Serikat itu memaksa untuk melakukan kegiatan jogging disaat Nyepi. Berikut dokumentasi WNA yang berjogging saat Nyepi:

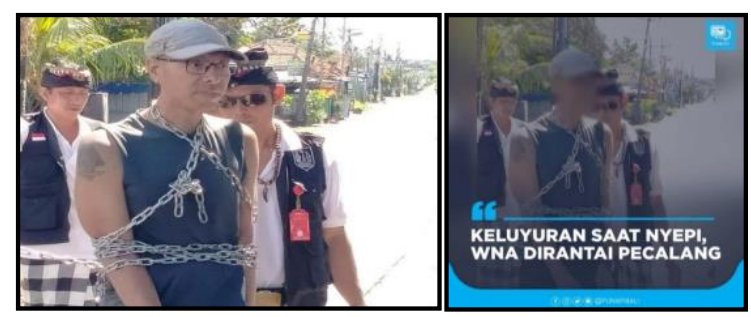

Gambar 4. Dokumentasi WNA Berjogging Saat Nyepi

Kepolisian ikut dikerahkan dalam kejadian ini, untuk memberikan penjelasan mengapa tidak diperbolehkannya siapapun berjalan-jalan di luar saat Penyepian. Reaksi wisatawan tersebut justru enggan mengurungkan niatnya dan mengatakan bahwa Penyepian merupakan kegiatan keagamaan umat Hindu. Wisatawan tersebut merasa bahwa dirinya orang Amerika Serikat sehingga tidak perlu mengikuti kegiataan keagaaman umat Hindu yang merupakan asal negara Indonesia, ia menegaskan urusan agama umat Hindu adalah urusan mereka, dan urusan wisatawan tersebut jogging adalah urusannya sehingga kehendaknya tidak dapat diganggu gugat. Berbagai upaya pengendalian sosial telah dilakukan pihak berwajib untuk mengurungkan niat dari wisatawan tersebut, tetapi tidak membuahkan hasil sehingga dilakukan upaya pengamanan dengan merantai bule itu agar tidak mencoba lari dan menerobos pecalang yang sedang bertugas di TKP.

Untuk menghindari terjadinya kasus serupa maka penyampaian materi tentang larangan orang ke luar rumah saat Penyepian akan dirasaKAN efektif untuk mengedukasi 
wisatawan yang tidak memahami adat istiadat yang berlaku di Bali. Penentuan materi "tidak bisa masuk pura saat menstruasi berdasarkan hasil survey yang dimana telah terjadi fenomena seorang wisatawan mancanegara asal Slovakia ini merupakan pemilik akun berinisial NM ini membuat video di platform TikTok, mengomentari larangan bagi perempuan di Bali dan Indonesia untuk memasuki pura ketika sedang menstruasi. Postingan tersebut kemudian menjadi perbincangan karena dikaitkan dengan diskriminasi bagi perempuan. Di video ini NM berkomentar dengan menunjuk papan peraturan memasuki pura. Pada poin larangan perempuan memasuki pura saat menstruasi. Berikut dokumentasi WNA yang mengkritik norma adat Bali melalui TikTok:

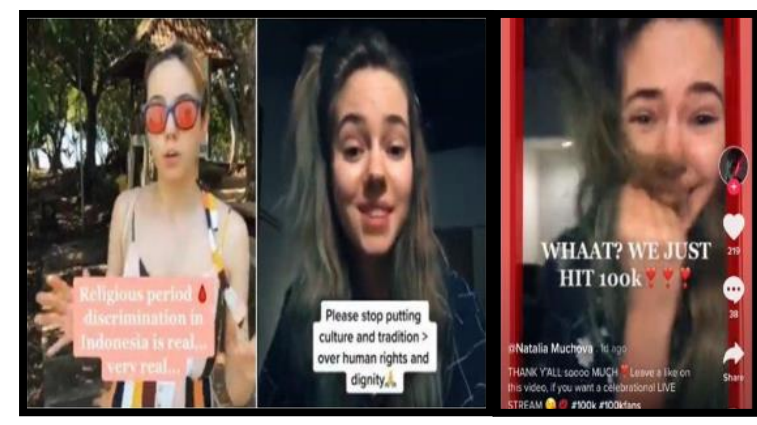

Gambar 5. Dokumentasi WNA Yang Mengkritik Norma Adat Bali Melalui TikTok

Unggahan tersebut ditonton sampai 320 ribu akun, di-retweet sampai 2.459 kali dan dikomentari sampai 722 kali sampai berita ini dibagikan. Setelah postingannya viral, ia kembali membuat video kedua yang berisikan alasan mengapa membuat video seperti itu, berikut kalimat yang ada pada video tersebut :

"Menstrual blood are considered impure ... and I made video about that, and that's not okay ...no matter the religion or tradition... With all respect ... you can't keep discriminating and make them feel embarassed.. for something so natural as periods..." (14 Maret 2020)

Artinya:

"Darah mens dikatakan tidak bersih ... lalu aku membuat video tersebut, dan itu tidak baik ... tidak peduli agama atau tradisi/ Dengan hormat ... kamu tidak bisa terus mendisikriminasi (wanita sedang haid) dan membuat mereka merasa malu akan sesuatu hal yang natural seperti haid". (14 Maret 2020)

Ketika konten TikToknya yang beredar luas dan menuai pro kontra, banyak dari netizen Indonesia yang menonton videonya dan tidak sedikit memberikan komentar, viewsnya hingga 100.000 penonton. Saat itu Natalia sangat senang dan membuat video untuk merayakan 100.000 penonton karena aksi kritiknya menaikkan jumlah viewersnya. Untuk menghindari terjadinya kasus serupa maka penyampaian materi tentang larangan bagi wanita yang sedang menstruasi memasuki pura dirasa brosur tersebut sangat efektif untuk mengedukasi wisatawan yang tidak memahami adat istiadat yang berlaku di Kabupaten Badung.

Setelah mekanisme penyebaran brosur dilaksanakan oleh stakeholder, masih saja banyak terjadinya penyimpangan perilaku wisatawan, tahapan selanjutnya para pelanggar akan dikenakan sanksi pengendalian sosial persuasif karena dianggap tidak patuh dengan peraturan, dan harus mengembalikan kesucian tempat ibadah seperti semula akan dilaksanakan upacara "Guru Piduka dan Bendu Piduka" sebagai pengendalian sosial represif.

\section{SIMPULAN DAN SARAN Simpulan}

Berdasarkan pembahasan pada artikel ini mengemukakan bahwa model pengendalian sosial preventif dalam menangani penyimpangan perilaku wisatawan mancanegara di Kabupaten Badung model merupakan suatu model preventif yang dapat dibentuk berdasarkan fakta ataupun fenomena yang sedang berkembang. Pengenalan bentukbentuk penyimpangan perilaku wisatawan mancanegara ditemukan 4 bentuk dan memiliki total 17 perilaku. Dari total bentuk penyimpangan tersebut dibutuhkannya pengendalian sosial dengan satu pendekatan, yaitu pendekatan preventif dengan 10 cara mengendalikan wisatawan mancanegara melakukan penyimpangan serta dibutuhkannya peran stakeholder pariwisata terlibat menjalankan pengendalian sosial secara preventif ini. Stakeholder yang dimaksud 
adalah masyarakat lokal; pemerintah dan pengusaha pariwisata. Setelah peran stakeholder dan penerapan pendekatan preventif dengan 10 cara maka dibutuhkannya pendekatan preventif lain dengan menerapkan mekanisme pembuatan brosur Do's and Dont's in Bali. llustrasi dalam sebuah brosur akan menarik minat pembaca untuk menerapkan saat berwisata di Kabupaten Badung dalam kehidupan sehari-hari. Penulis mengkemas materi pengendalian sosial preventif dalam konteks himbauan dan sedikit pemahaman tentang perilaku yang bisa dilakukan dan yang tidak bisa dilakukan di Bali. Diharapkan dengan adanya penyebaran brosur ini akan dapat mengedukasi wisatawan mancanegara dalam mengantisipasi ketidak-tahuannya akan normanorma yang berlaku di Kabupaten Badung. Setelah mekanisme penyebaran brosur dilaksanakan oleh stakeholder, dan masih saja banyak terjadinya penyimpangan perilaku wisatawan, tahapan selanjutnya para pelanggar akan dikenakan sanksi.

\section{Saran}

Berdasarkan hasil dari pembahasan dalam artikel ini, maka saran yang dapat direkomendasikan kepada pemerintah yaitu :

1. Upaya pengendalian sosial preventif penyebaran brosur Do's and Dont's in Bali dirasa efektif baik secara hardcopy maupun softcopy juga bisa diterapkan di Kabupaten lainnya di Bali.

2. Pemerintah melalui Desa Adat agar lebih tegas menangani penyimpangan perilaku wisatawan mancanegara dan perlu di buatkan parerem Desa Adat. 


\section{Kepustakaan}

Anonim. Peraturan Gubernur Bali No 4 Tahun 2019 Tentang Desa Adat.

Bali Puspa, News. 2020. Ngotot Jogging Wisatawan Asal Amerika Dirantai Pecalang.

https://www.balipuspanews.com/ngototjoggingwisatawan-asal-amerikadirantai-pecalang.html. Diakses pada 30 Maret 2020.

Bidell \& Deacon. 2010. School Counselors Connecting the Dots Between Disruptive Classroom Behavior and Youth SelfConcept.

Bovee, Courtland L., et al. 1995. Marketing. 2 nd ed. McGraw - Hill, Inc., New York.

News, Tribun Medan. 2020. Bule Slovakia Sebut Budaya Indonesia Diskriminatif, Kesal Lantaran Tak Boleh Masuk Pura saat Haid. https://medan.tribunnews.com/2020/03/ 13/bule-slovakia-sebut- budayaindonesia-diskriminatif-kesal-lantarantak-boleh-masuk-purasaathaid?page $=2$. Diakses pada 06 Mei 2020
Patton, M. (1990). Qualitative evaluation and research methods. California: Sage Publications.

Pendidikan, Dosen. 2014. Contoh Brosur. http: //www.dosenpendidikan.co.id/contohbrosur/. Diakses pada 14 juni 2020

Pia Todras. 2007. Teachers Perspective of Disruptive Behavior in the Classroom. Dessertation. Faculty of the Chicago School of Professional Psychology.

Pitana, I. G. dan Gayatri, P. G. 2005. Sosiologi Pariwisata. Yogyakarta : Andi Offset.

Pitana, I Gde dan I Ketut Surya Diarta. 2009. Pengantar Ilmu Pariwisata. Jakarta: Andi. 